\title{
Tribute to Dr. Mario Augusto Taricco
}

\section{Homenagem ao Dr. Mário Augusto Taricco}

\author{
Eduardo de Arnaldo Silva Vellutini ${ }^{1}$ Felix Hendrik Pahl ${ }^{1}$ Matheus Fernandes de Oliveira ${ }^{10}$ \\ ${ }^{1}$ Neurosurgery Department, DFV NEURO, São Paulo, SP, Brazil \\ Address for correspondence Matheus Fernandes de Oliveira, MD, \\ PhD, IAMSPE, Av. Loefgren 700, 103, Vila Mariana, São Paulo, São \\ Arq Bras Neurocir \\ Paulo, 04040-000, Brazil (e-mail: mafernoliv@yahoo.com.br).
}

\begin{abstract}
The present article is a brief tribute to Dr Mario Augusto Taricco, highlighting his contributions to Brazilian neurosurgery during his prestigious professional career. Dr Taricco was born in São Paulo, state of São Paulo, Brazil, and contributed to neurosurgery and spinal surgery for 42 years, leaving a vast legacy for São Paulo's and national neurosurgery. Based on values such as discipline, ethics, professionalism and competence, he built his own brand leading and improving neurosurgery and spine surgery in Brazil. He graduated in the Escola Paulista de Medicina and became

Keywords

- Mário Taricco

- neurosurgery

- spinal surgery

- history

\section{Resumo}

\section{Palavras-chave}

- Mário Taricco

- neurocirurgia

- cirurgia da coluna vertebral

- história neurosurgeon at the Hospital das Clínicas of the Universidade de São Paulo (FMUSP, in the Portuguese acronym). Since 1989, he became the head of the Spine Surgery Group of the Neurosurgery Service of Hospital das Clínicas, FMUSP. A career dedicated to professional and academic excellence, focused on patient treatment and science improvement.

O presente artigo é uma breve homenagem ao Dr. Mario Augusto Taricco, destacando suas contribuições à neurocirurgia brasileira durante sua prestigiada carreira profissional. O Dr. Taricco nasceu em São Paulo, SP, e contribuiu com a neurocirurgia e cirurgia da coluna vertebral por 42 anos, deixando um vasto legado material e imaterial para a neurocirurgia nacional. Com base em valores como disciplina, ética, profissionalismo e competência, ele construiu sua própria marca liderando e aprimorando a neurocirurgia e a cirurgia da coluna no Brasil. Ele se graduou na Escola Paulista de Medicina e fez residência em neurocirurgia no Hospital das Clínicas da Faculdade de Medicina da Universidade de São Paulo (FMUSP). Desde 1989, tornou-se chefe do Grupo de Cirurgia da Coluna do Serviço de Neurocirurgia do Hospital das Clínicas da FMUSP. Uma carreira dedicada à excelência profissional e acadêmica, focada no tratamento de pacientes e no aprimoramento da ciência.
\end{abstract}

After communicating his retirement, we pay a simple and deserved tribute to Prof. Dr Mario Augusto Taricco, or simply Dr Taricco (-Fig. 1). Dr Taricco leaves a vast legacy for national neurosurgery. Based on values such as discipline, ethics, professionalism and competence, he built his own brand leading and improving neurosurgery and spine surgery in Brazil.

received

May 23, 2020

accepted

September 15, 2020
DOI https://doi.org/

10.1055/s-0040-1719011. ISSN 0103-5355.
Dr Taricco was born in São Paulo, state of São Paulo, Brazil. He graduated in medicine at the Escola Paulista de Medicina in 1974. Later, he completed his training in neuropsychiatry and neurosurgery at the Hospital das Clínicas, Universidade de São Paulo (FMUSP, in the Portuguese acronym) from 1975 to 1978 . At that moment, neurosurgical residency had the leadership of Prof. Dr. Gilberto Machado de Almeida. In 1978,

Copyright (c) by Thieme Revinter Publicações Ltda, Rio de Janeiro, Brazil 


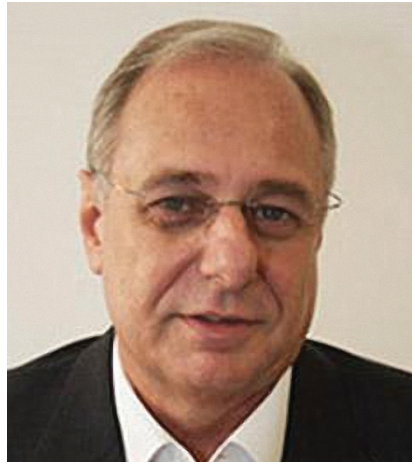

Fig. 1 Picture of Dr Mário Augusto Taricco.

at the end of the residency, he applied for national specialty examination. From then until 2018, he attended all the Congresses of the Brazilian Society of Neurosurgery.

Additionally, Dr Taricco improved his training in the following years in courses and fellows in New York, Miami and Gainesville. In Brazil, he performed complementary training at the Orthopedics and Traumatology Institute (IOT, in the Portuguese acronym) of the Hospital das Clínicas, Universidade de São Paulo in 1980 for 4 years under the supervision of Dr Antônio Bento Furtado de Mendonça (Prof. Dr. Aldo Fazzi and Dr Roberto Basile were also staff members), being a colleague of Dr. Reginaldo de Oliveira, Dr. Julia D'Andrea Greve and Dr. Tarcisio Eloi Barros Filho. The latter is currently the chairman at the Department of Orthopedics and Traumatology.

Since 1989, he became the Head of the Spine Surgery Group of the Neurosurgery Service of the Hospital das Clínicas, FMUSP. From that moment on, he decided to develop and improve the status of spine surgery, which until then had been mainly performed by orthopedic surgeons. Leading the Spine Surgery Group, he continued the work of great masters of neurosurgery, such as Dr. José Luzio, Dr. Luiz Alcides Manreza and Dr. Walter Carlos Pereira. He has also learned with Dr. Clemente Augusto de Brito Pereira.

In 1995, he became a $\mathrm{PhD}$ with the thesis "Surgical Treatment of Syringomyelia Associated with Malformation of Type I Chiari". In 2001, he became Professor of Neurosurgery Discipline of the Neurology Department at FMUSP. He became an Associate Professor in 2006, teaching medicine graduation students. Within the Neurosurgery Department of the Hospital das Clínicas of FMUSP he enjoyed immense respect for his peers, sharing the leading role with names such as Gilberto Machado de Almeida, Raul Marino Jr, Evandro de Oliveira, Manoel Jacobsen Teixeira, José Marcus Rotta, Mário Siqueira, Hamilton Matushita, Nilton Cabral, Eduardo Vellutini, Felix Pahl, Guilherme Carvalhal Ribas, Luis Alcides Manreza, José Luzio, among others.

He used to stay close to the residents at the visit in hospital wards and patient's beds, and always gave his opinion during department grand rounds. He was also an example for residents in matters of punctuality, attendance and dedication to teaching and surgery. He always examined the patient thoroughly and correlated the neurological examination with the complementary image evaluation.
Soon he came to stand out in the leadership of the Spinal Surgery group, occupying a notorious place within the institution and in the neurosurgery and spine surgery medical societies. He was a pioneer in the use of microscopy in spine surgery, also contributing to spread the use of retractors and to reduce incision size and surgical trauma. He was a regular attendant of the main scientific events in spine surgery in Brazil, such as the Brazilian Congress of Spine, Brazilian Congress of Spinal Surgery and Brazilian Congress of Neurosurgery.

Dr. Taricco always had an outstanding performance in scientific events, always inquiring and discussing the concepts with presenters and audience. His professional, scientific quality and impeccable performance led him to lead the Brazilian Spine Society in the 2009-2010 biennium, being the first neurosurgeon to occupy the position. He has also become a member of AOSpine since 2005, participating in courses and events. He was the president of the Spine Department of the Brazilian Society of Neurosurgery from 1998 to 2000 and vice-president of the Brazilian Society of Neurosurgery from 2000 to 2002.

Dr. Taricco also had an important private clinic. In 1989, he joined young neurosurgeons Dr. Eduardo Vellutini, Dr. Felix Pahl and neurologist Dr. Eduardo Mutarelli, becoming part of the DFV Neuro team. The initial field of action was at the Hospital Alemão Oswaldo Cruz, later expanding to other important private health institutions, including the Hospital Sírio-Libanês, the Hospital Albert Einstein, the Hospital 9 de Julho and the Hospital Santa Catarina. Today, the DFV Neuro neurosurgical team also includes Drs. Alberto Capel, Marcos Teles Gomes, Roger Brock, José Erasmo DaíCol Lúcio, José Francisco Pereira Jr, Matheus Fernandes and Clarissa Nascimento.

In the scientific field, he supervised PhD theses, organized events, composed countless Master of Science and PhD evaluation boards as an evaluator. He participated in the edition of relevant books and chapters, always with a main focus on spine surgery. Additionally, he published 61 scientific articles in indexed journals, dealing with the main spinal diseases, with emphasis on diseases of the craniocervical junction, cervical spondylotic compression disease and spinal cord tumors.

Currently at the height of his successful professional career, Dr. Taricco is a senior member of the DFV Neuro team, of the Brazilian Neurosurgery Societies, the American Spine Injury Association, the North American Spine Society (2005), the Brazilian Society of Spinal Cord Injury Studies, the American Association of Neurological Surgeons, the World Federation of Neurosurgical Societies and the Brazilian Society of Spine Pathology. Recently, he was honored during the XXXI Brazilian Congress of Neurosurgery (2016) in Brasília.

Many generations of residents of the Hospital das Clínicas learned the concepts and surgical technique directly from him. He trained prominent professionals in spine surgery, such as Osmar Moraes, Alberto Capel, Arthur Poetscher, Roger Brock, Ricardo Fontes and many other residents and fellows. Directly or indirectly, he is responsible for the 
Tribute to Dr. Mario Augusto Taricco Vellutini et al.

dissemination of many of the concepts learned today in the main training centers in the country.

Dr Taricco has always been very serious and committed to the evaluation and care of the patient. Outside work, he is a sympathetic and always in good humor person. Married to Dr. Solange Delboni Taricco, he has two daughters (Adriana and Luciana, judge and physiatrist) and 3 granddaughters. Very fond of family and the warmth of home, he spends his moments of rest at his farm in Santa Rita do Passa Quatro, in the countryside of São Paulo, where he dedicates himself to raising horses. He loves to welcome family and to be an affectionate husband, father and grandfather.

\section{Acknowledgments}

We would like to thank DFV Neuro's partners for helping in the task of preparing the present tribute. Thus, we would like to thank Drs. Eduardo Mutarelli, Alberto Capel, Marcos Teles Gomes, Roger Brock, José Erasmo DaíCol Lúcio, José Francisco Pereira Jr and Clarissa Nascimento. 